\title{
STUDY OF HISTOPATHOLOGICAL CHANGES IN LUNGS AND KIDNEYS FOLLOWING DEATH DUE TO BURNS AT VARYING PERIODS OF SURVIVAL
}

\author{
Sathikumar $M^{1}$
}

${ }^{1}$ Associate Professor, Department of Forensic Medicine, SUT Academy of Medical Sciences, Vattappara, Thiruvananthapuram.

ABSTRACT
BACKGROUND
In the present study, aetiological factors leading to death from burns; pattern of burns; the environment in which the incident
occurs, depth and percentage of burns, effect of clothing on the distribution and extent of burns sustained. The changes occurring in
the internal organs like lungs and kidneys of victims died of burns and period of survival after sustaining burns are studied in detail.
With this background, the lungs and kidneys of the victims died of burns were subjected for detailed histopathological examination
and the various pathological changes occurred in them are studied.

\section{MATERIALS AND METHODS}

The study was conducted at Government Medical College, Kozhikode. During the period of 1 year, 60 cases of death due to burn from the fire were studied.

\section{RESULTS}

It was noted that majority of lung specimen showed histopathological changes like alveolar oedema and congestion, bronchiolar congestion and haemorrhage, interstitial oedema, haemorrhage, congestion, and inflammation. The kidneys showed acute tubular necrosis and haemorrhage, glomerular haemorrhage and oedema, interstitial necrosis, haemorrhage and congestion as histopathological changes.

\section{DISCUSSION AND CONCLUSION}

From this study at different periods of survival in burns of two organs, the histopathological changes of lungs and kidneys are more prominent. When the period of survival increased, i.e., these organs undergoes severe and very severe degree of changes. Most of the subject died of acute pulmonary oedema, bronchopneumonia, renal failure, and septicaemia in late period of survival. Hence, on conclusion from the study that the lungs and kidneys are two internal organs, which show constant histopathological changes in cases of death due to burns irrespective of the period of survival and these organs are more important in determining the cause of death.

\section{KEYWORDS}

Histopathological Changes, Survival, Grading, Necrosis.

HOW TO CITE THIS ARTICLE: Sathikumar M. Study of histopathological changes in lungs and kidneys following death due to burns at varying periods of survival. J. Evolution Med. Dent. Sci. 2016;5(61):4301-4304, DOI: 10.14260/jemds/2016/981

\section{INTRODUCTION}

Burns arise in a number of accidental situations and may have a variety of accompanying injuries or pre-existing medical problems associated with the burn injury scalds, flame or thermal burns, chemical and electrical burns all will produce a different burn pattern and inhalation of smoke and toxic chemicals from the fire may cause serious accompanying complications. J.W.L Davies (1990) ${ }^{1}$ estimates the incidence of burning injury in the Indian subcontinent are unlikely to be more than relatively informed guesses. One often quoted estimate for a population of 800 million is 2 million burn injuries per year that are more than trivial, 5,00,000 of which receive clinic or hospital outpatient care. Kuliyapin A V et al $(1990)^{2}$ states that in June 1989 a methane/propane pipeline

Financial or Other, Competing Interest: None.

Submission 23-06-2016, Peer Review 17-07-2016,

Acceptance 23-07-2016, Published 01-08-2016.

Corresponding Author:

Dr. Sathikumar $M$,

Associate Professor,

Department of Forensic Medicine,

SUT Academy of Medical Sciences,

Vittapara,

Thiruvananthapuram.

E-mail: drsathikumar6@gmail.com

DOI: $10.14260 /$ jemds/2016/981 explosion destroyed two passenger trains in the Bashkirian Republic of Soviet Union.

During the period, 60 cases of burn deaths were studied. Of these 60 cases, 39 deaths were suicidal comprising 65\%, 20 accidental comprising $33.33 \%$, and one case was homicidal constituting $1.67 \%$.

Regarding period of survival of these 60 cases, 7 subjects died immediately (11.67\%), 17 subjects died within 1 hour to 24 hour (28.34\%), 21 subjects died within 1 day to 7 days (35\%), 11 subjects died within 8 days to 14 days (18.33\%), 2 subjects died within 15 days to 21 days (3.33\%), and 2 subjects died within 22 to 28 days (3.33\%). Figure 1.

There are certain pathological changes such as lungs show diffuse alveolar damage, bronchiolar congestion, and interstitial oedema. Toor A H, Tomashefski JF Jr, Kleinerman J (1990). ${ }^{3}$ According to Walter and I C Talbot (1996) ${ }^{4}$ the kidneys are usually swollen and the cortex is mainly affected and appears pale. Sevitt (1957) 5 described two patterns of change in renal failure after burning, distal tubular necrosis, and proximal tubular necrosis. With this, present study was planned to work out the histopathological examination of lungs and kidneys has been done to see changes at varying period of survival and their utility to predict prognosis and give better treatment for patients in future life. 


\section{MATERIALS AND METHODS}

The duration of study was 1 year and was conducted at Government Medical College, Kozhikode. During the period of 1 year, 60 cases of death due to burns from fire was studied. From all the 60 cases, bits were taken from lungs and kidneys and preserved in $10 \%$ formalin and the histopathological study of these organs in all cases were done. Pathological changes, which occurred in these organs of all the 60 cases were noted after studying the slides and the changes noted in these organs in the case of immediate death and subsequent deaths were noted and grouped into six grades according to the period of survival. In cases in which death was not immediate and being admitted to the hospital, the details of treatment were also noted after perusal of their case sheets.

Previous history of any illness leading to lungs and kidney changes has been excluded from history of previous illness and treatment.

\section{OBSERVATIONS AND RESULTS}

Histopathological changes of internal organs lungs and kidneys were studied at various period of survival and grouped into VI groups, i.e., changes during immediate death, changes during 1 hour to 24 hours, changes during 1 day to 7 days, during 8 to 14 days, during 15 to 21 days, and changes during 22 to 28 days of survival.

Depending upon the severity of histopathological changes of lungs and kidneys, again each organ changes were graded into Grade I (Mild degree of changes), Grade II (Moderate degree of changes), Grade III (Severe degree of changes), Grade IV (Very severe degree of changes).

The main histopathological changes of lungs and kidneys are shown in Table 1.

In case of immediate death; in Grade I, $1+$ to $3+$ were considered; in Grade II, 4+ to 6+ were considered; in Grade III, $7+$ to $9+$ were considered; in Grade IV, $10+$ to $12+$ and above were considered. In case of other 5 groups, in Grade I, $1+$ to 4+; in Grade II, 5+ to 8+; in Grade III, 9+ to 12+; and in Grade IV, $13+$ to $16+$ and above were considered.

Regarding histopathological changes of lungs in the case of immediate death, lungs showed $14.29 \%$ of Grade I changes, $14.29 \%$ of Grade II changes, $28.57 \%$ of Grade III changes, and $42.85 \%$ of Grade IV changes.
Kidneys showed $28.57 \%$ of Grade I, $28.57 \%$ of Grade II changes, $14.29 \%$ of Grade III, and $28.57 \%$ of Grade IV changes (Photo 1.). Table 2.

During the period of 1 to 24 hours, histopathological changes of lungs showed $11.76 \%$ of Grade I changes, $23.54 \%$ of Grade II changes, $5.88 \%$ of Grade III, and $58.82 \%$ of Grade IV changes.

While kidney showed $5.88 \%$ of Grade I changes, $47.06 \%$ of Grade II changes, $23.53 \%$ of Grade III, and $23.53 \%$ of Grade IV changes. Table 3.

Considering the period of survival, 1 to 7 days, lungs showed $14.29 \%$ of Grade I changes, $23.81 \%$ of Grade II changes, $19.05 \%$ of Grade III, and $42.85 \%$ of Grade IV changes (Photo 2.). Whereas kidneys showed $19.05 \%$ of Grade I changes, $47.61 \%$ of Grade II changes, $19.05 \%$ of Grade III, and $14.29 \%$ of Grade IV changes (Photo 3.). Table 4.

Regarding the period of survival, 8 to 14 days, histopathological changes of lungs showed $9.09 \%$ of Grade I changes, $36.36 \%$ of Grade II, $18.19 \%$ of Grade III, and $36.36 \%$ of Grade IV (Photo 4.). Whereas kidneys showed 9.09\% of Grade I, $54.55 \%$ of Grade II, $27.27 \%$ of Grade III, and $9.09 \%$ of Grade IV. Table 5.

During the period of survival, 15 to 21 days, histopathological changes of lungs were $100 \%$ of Grade I. Meanwhile, kidneys showed $50 \%$ of Grade II and $50 \%$ of Grade III changes. Table 6.

In the case of histopathological changes during the period of survival, 22 to 28 days, lungs showed $50 \%$ of Grade III and $50 \%$ of Grade IV changes. Kidneys showed $100 \%$ of Grade III changes. Table 7.

\begin{tabular}{|c|c|}
\hline Organs & Histopathological Changes \\
\hline Lungs & $\begin{array}{l}\text { Alveolar oedema and congestion } \\
\text { Bronchiolar congestion and haemorrhage } \\
\text { Interstitial oedema, haemorrhage and } \\
\text { congestion, inflammation }\end{array}$ \\
\hline Kidneys & $\begin{array}{l}\text { Tubular necrosis and haemorrhage, } \\
\text { Glomerular haemorrhage and oedema, } \\
\text { Interstitial necrosis, haemorrhage and } \\
\text { congestion. }\end{array}$ \\
\hline \multicolumn{2}{|r|}{$\begin{array}{c}\text { Table 1: The Main Histopathological Changes } \\
\text { of Lungs and Kidneys }\end{array}$} \\
\hline
\end{tabular}

\begin{tabular}{|c|c|c|c|c|c|c|c|c|}
\hline Organs & $\begin{array}{c}\text { Grade I 1+ } \\
\text { to 3+ } \\
\text { (Mild) }\end{array}$ & $\%$ & $\begin{array}{c}\text { Grade II 4+ to } \\
\text { 6+ (Moderate) }\end{array}$ & $\%$ & $\begin{array}{c}\text { Grade III 7+ } \\
\text { to 9+ } \\
\text { (Severe) }\end{array}$ & $\%$ & $\begin{array}{c}\text { Grade IV 10+ to } \\
\text { 12+ and above } \\
\text { (Very Severe) }\end{array}$ & $\begin{array}{c}\text { \% } \\
\text { Lungs }\end{array}$ \\
\hline Kidneys & 2 & 14.29 & 1 & 14.29 & 2 & 28.57 & 3 & 42.85 \\
\hline
\end{tabular}

\begin{tabular}{|c|c|c|c|c|c|c|c|c|}
\hline Organs & $\begin{array}{c}\text { Grade I 1+ } \\
\text { to 3+ } \\
\text { (Mild) }\end{array}$ & $\%$ & $\begin{array}{c}\text { Grade II 4+ to } \\
\mathbf{6 +} \text { (Moderate) }\end{array}$ & $\%$ & $\begin{array}{c}\text { Grade III 7+ } \\
\text { to 9+ } \\
\text { (Severe) }\end{array}$ & $\%$ & $\begin{array}{c}\text { Grade IV } \\
\text { 10+to12+ and } \\
\text { above (Very } \\
\text { Severe) }\end{array}$ & $\begin{array}{c}\% \\
\text { Lungs }\end{array}$ \\
\hline Kidneys & 1 & 11.76 & 4 & 23.54 & 1 & 5.88 & 10 & 58.82 \\
\hline
\end{tabular}




\begin{tabular}{|c|c|c|c|c|c|c|c|c|}
\hline Organs & $\begin{array}{c}\text { Grade I1+ } \\
\text { to } 3+ \\
\text { (Mild) }\end{array}$ & $\%$ & $\begin{array}{l}\text { Grade II 4+ to } \\
6+\text { (Moderate) }\end{array}$ & $\%$ & $\begin{array}{c}\text { Grade III 7+ } \\
\text { to 9+ } \\
\text { (Severe) }\end{array}$ & $\%$ & $\begin{array}{l}\text { Grade IV } 10+\text { to } \\
12+\text { and above } \\
\text { (Very Severe) }\end{array}$ & $\%$ \\
\hline Lungs & 3 & 14.29 & 5 & 23.81 & 4 & 19.05 & 9 & 42.85 \\
\hline Kidneys & 4 & 19.05 & 10 & 47.61 & 4 & 19.05 & 3 & 14.29 \\
\hline
\end{tabular}

\begin{tabular}{|c|c|c|c|c|c|c|c|c|}
\hline Organs & $\begin{array}{c}\text { Grade I 1+ } \\
\text { to 3+ } \\
\text { (Mild) }\end{array}$ & $\%$ & $\begin{array}{c}\text { Grade II 4+ to } \\
\text { 6+ (Moderate) }\end{array}$ & $\%$ & $\begin{array}{c}\text { Grade III 7+ } \\
\text { to 9+ } \\
\text { (Severe) }\end{array}$ & $\%$ & $\begin{array}{c}\text { Grade IV } \\
\text { 10+to12+ and } \\
\text { above (Very } \\
\text { Severe) }\end{array}$ & $\begin{array}{c}\% \\
\text { (Mere }\end{array}$ \\
\hline Lungs & 1 & 9.09 & 4 & 36.36 & 2 & 18.19 & 4 & 36.36 \\
\hline Kidneys & 1 & 9.09 & 6 & 54.55 & 3 & 27.27 & 1 & 9.09 \\
\hline \multicolumn{2}{|c|}{ Table 5: Histopathological Changes of Lungs and Kidneys - Grading Period of Survival 8 Days to 14 Days } \\
\hline
\end{tabular}

\begin{tabular}{|c|c|c|c|c|c|c|c|c|}
\hline Organs & $\begin{array}{c}\text { Grade I 1+ to } \\
\text { 3+ (Mild) }\end{array}$ & $\%$ & $\begin{array}{c}\text { Grade II 4+ to 6+ } \\
\text { (Moderate) }\end{array}$ & $\%$ & $\begin{array}{c}\text { Grade III 7+ } \\
\text { to 9+ } \\
\text { (Severe) }\end{array}$ & \% & $\begin{array}{c}\text { Grade IV 10+to12+ } \\
\text { and above (Very } \\
\text { Severe) }\end{array}$ & $\begin{array}{c}\text { \% } \\
\text { Lungs }\end{array}$ \\
\hline Kidneys & 0 & 0 & 0 & 0 & 0 & 0 & 2 & 100 \\
\hline
\end{tabular}

Table 6: Histopathological Changes of Lungs and Kidneys - Grading Period of Survival 15 Days to 21 Days

\begin{tabular}{|c|c|c|c|c|c|c|c|c|}
\hline Organs & $\begin{array}{c}\text { Grade I 1+ to } \\
\mathbf{3 +} \text { (Mild) }\end{array}$ & $\%$ & $\begin{array}{c}\text { Grade II 4+ to 6+ } \\
\text { (Moderate) }\end{array}$ & $\mathbf{\%}$ & $\begin{array}{c}\text { Grade III 7+ } \\
\text { to 9+ } \\
\text { (Severe) }\end{array}$ & $\mathbf{\%}$ & $\begin{array}{c}\text { Grade IV 10+to12+ } \\
\text { and above (Very } \\
\text { Severe) }\end{array}$ & $\begin{array}{c}\text { \% } \\
\text { Lungs }\end{array}$ \\
\hline Kidneys & 0 & 0 & 0 & 0 & 1 & 50 & 1 & 50 \\
\hline
\end{tabular}

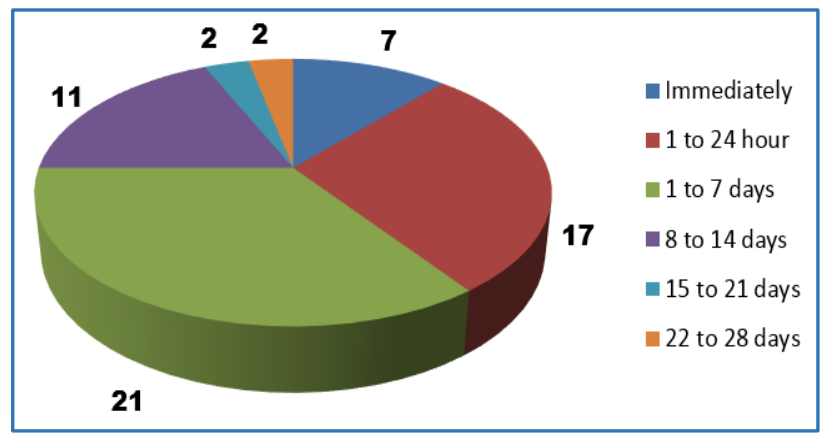

Fig. 1: Period of survival

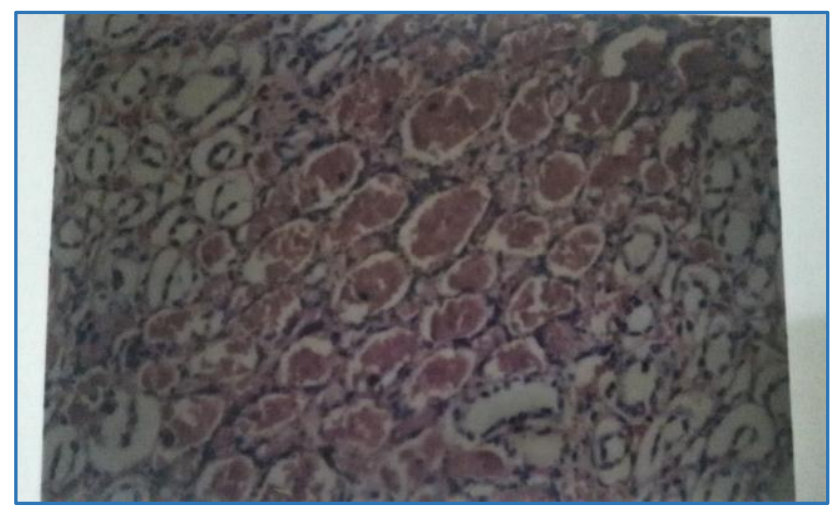

Photo 1: Immediate Death. Kidney Showing Severe Congestion of Tubules

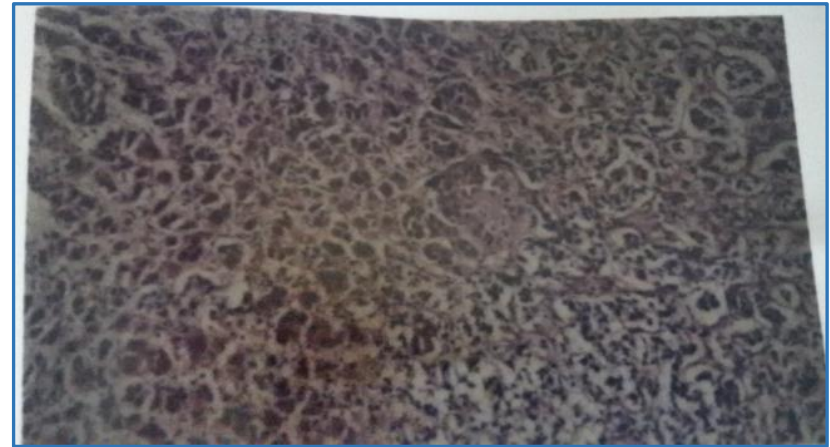

Photo 2: Period of Survival 3 Days 9 Hours. Lung Showing Alveolar Oedema, Congestion, Haemorrhage, and Necrosis; Interstitium Showed Severe Oedema, Necrosis, and Inflammation

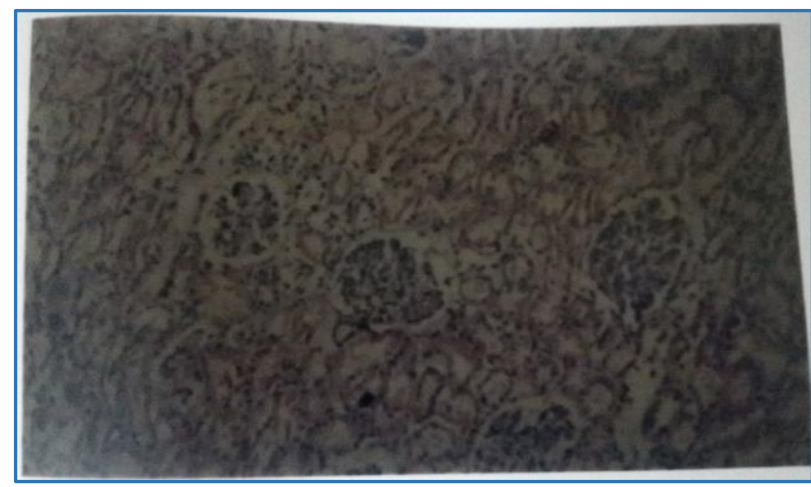

Photo 3: Period of Survival 3 Days 10 Hours. Kidney Showing Tubular Oedema, Congestion, Glomerular Haemorrhage, Interstitial Oedema, and Inflammation 


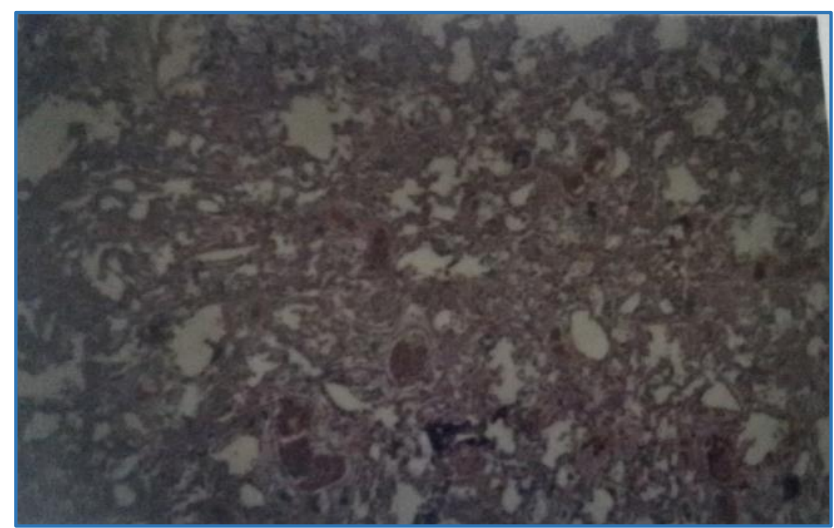

Photo 4: Period of Survival 11 Days 15 Hours. Lung Showing Alveolar Congestion, Haemorrhage and Oedema, Interstitial Oedema, Congestion and Haemorrhage, and Carbon-Laden Macrophages

\section{DISCUSSION}

In this study, 51 subjects died with deep burns and rest with superficial burns. Of these 60 cases, 7 subjects died immediately. Lungs showed $52.85 \%$ of Grade IV changes, i.e., very severe degree changes of alveolar oedema, haemorrhage, bronchiolar haemorrhage, interstitial haemorrhage, congestion and inflammation. But, $28.57 \%$ of Grade III, i.e., severe degree changes and $14.29 \%$ each of Grade I and Grade II changes. These findings are similar to the study of heat injuries to the respiratory system in case of instantaneous death by Brinkmann et al (1979).6 Kidneys showed 28.57\% each of Grade I, Grade II, and Grade IV changes. In other words, mild, moderate, and very severe-degree changes of renal tubular necrosis, glomerular oedema and haemorrhage and necrosis, interstitial haemorrhage, oedema and inflammation. Grade III changes of kidney are $14.29 \%$.

During the period of survival 1 hour to 24 hours here, lung changes include $58.82 \%$ of Grade IV changes, i.e., very severe histopathological changes of alveolar oedema, haemorrhage, congestion and necrosis, and bronchiolar haemorrhage. These findings are similar to the study of cellular responses in the lungs of rabbits and the morphologic features of tracheobronchial tree were examined 24 hours following acute inhalation by Loke J et al (1984). ${ }^{7}$ Lungs also showed $23.54 \%$ of Grade II, $11.76 \%$ of Grade I, and $5.88 \%$ of Grade III changes. Kidneys showed $47.06 \%$ of Grade II changes, i.e., moderate degrees of tubular cell necrosis, glomerular oedema, and haemorrhage, and $23.53 \%$ each of Grade III and Grade IV, and $5.88 \%$ of Grade I changes. These findings are not similar with the study of kidney tubular cell proliferation in the burned mice by Asko-Seljavaara S (1975). ${ }^{8}$

During the period of survival 1 day to 7 days of burns death, the histopathological changes lungs include $42.85 \%$ of Grade IV, i.e., very severe degree and $23.81 \%$ of Grade II changes. The rest of the percentage of changes include Grade III and Grade I. Kidneys showed $47.61 \%$ of Grade II, i.e., moderate degree and Grade IV, i.e., very severe degree of changes is $14.29 \%$. The rest of percentage were Grade III and Grade I changes.

Regarding the period of survival of 8 days to 14 days, the histopathological study of lungs showed equal percentage of Grade II and Grade IV changes, $36.36 \%$ of each are observed in moderate and very severe degree of changes of alveolar oedema with congestion. But, this finding is similar to the study of Loke J et al (1984) and Guo ZR (1990)9. In this period of survival, kidneys showed $54.55 \%$ of changes in Grade II and $27.27 \%$ of Grade III, i.e., moderate and severe degree changes of tubular necrosis, haemorrhage, interstitial oedema, and congestion. These findings are similar to study of Sevitt (1957). According to Walter (1996) and Weiss SM et al (1994),10 interstitial oedema is a characteristic and useful histologic sign.

During the period of survival 15 days to 21 days, lungs showed $100 \%$ of Grade IV, i.e., very severe degree of changes. Kidneys changes are $50 \%$ each of Grade II and Grade III changes, i.e., moderate and severe degree of changes.

Regarding the last group, the period of survival of 22 to 28 days, the histopathological study of lungs are $50 \%$ each of Grade III and Grade IV changes and kidney changes are 100\% Grade III changes.

\section{Inference}

In this present study at different period of survival in burns, the histopathological changes of lungs and kidneys are more prominent. When the period of survival increase the histopathological changes increased, i.e. these organs undergo severe and very severe degree of changes. But, in early period of survival and in immediate death, lungs and kidney changes are different, i.e. lungs and kidneys showed all the four grades of changes at various patterns and most of the subjects died of acute pulmonary oedema and renal failure. Hence, it is reasonably concluded from this study that the lungs and kidneys are two internal organs, which show various histopathological changes in cases of death due to burns irrespective of the period of survival and these organs are more important in determining the cause of death.

\section{REFERENCES}

1. Davies JWL. The problems of burns in India. The Journal of the International Society for Burn Injuries 1990;16(Suppl 1):S1-24.

2. Kuliyapin AV, Sakhautdinov VG, Tamerbulatov VM, et al. Bashkiria train-gas pipeline disaster. A history of the joint USSR/USA collaboration. Burns 1990;16(5):339-42.

3. Toor AH, Tomashefski JF, Kleinerman J. Respiratory tract pathology in patients with severe burns. Hum Pathol 1990;21(12):1212-20.

4. Walter JB, Talbot IC. General Pathology. $7^{\text {th }}$ ed. Edinburg: Churchill Livingstone 1996:pp 768.

5. Sevitt S. Burns: pathology and therapeutic applications. London: Butterworth and Co Ltd 1957.

6. Brinkmann B, Kleiber M, Koops E, et al. Acute death from scalding: vital reactions. Z Rechtsmed 1979;83(1):1-16.

7. Loke J, Paul E, Virgulto JA, et al. Rabbit lung after acute smoke inhalation. Cellular responses and scanning electron microscopy. Arch Surg 1984;119(8):956-9.

8. Asko-Seljavaara S. Kidney tubular cell proliferation in burned mice. Scand J Plast Reconstr Surg 1975;9(1):2530.

9. Guo ZR. Pulmonary oedema in an isolated lobe after inhalation injury. Zhonghua Zheng Xing Shao Shang Wai Ke Za Zhi 1990;6(2):121-4, 159.

10. Weiss SM, Lakshminarayanan S. Acute inhalation injury. Clin Chest Med 1994;15(1):103-16. 